\title{
PEMBERDAYAAN ANGGOTA MAJELIS TA'LIM AL-IKHLAS MELALUI KEGIATAN KETERAMPILAM MERAJUT DI DADOK TUNGGUL HITAM PADANG
}

\author{
Zeshasina Rosha ${ }^{1}$, Linda Wati ${ }^{2}$, Ice Kamela ${ }^{3}$, Arfan Ananda ${ }^{4}$, Fisti Dea $\mathrm{M}^{5}$ \\ $1,2,3,4,5$ Management Department, Faculty of Economics, Bung Hatta University, Indonesia \\ 'zeshasina@yahoo.com, ${ }^{2}$ lindawati@bunghatta.ac.id, ${ }^{3}$ icekamela@yahoo.com, ${ }^{4}$ arfanda@gmail.com, \\ fistidea@gmail.com
}

\begin{abstract}
ABSTRAK
Abstrak: Kecamatan Koto Tangah adalah Kecamatan yang paling padat penduduknya. Kecamatan ini memiliki jumlah penduduk perempuan yang cukup besar. Pemberdayaan perempuan sangat penting dilakukan untuk memiliki jiwa kewirausahaan dalam mengembangkan ekonomi produktif. Pemberdayaan perempuan untuk meningkatkan akses terhadap pengetahuan dan keterampilan, sehingga dapat meningkatkan kesejahteraan keluarga. Kegiatan pelatihan keterampilan diharapkan berdampak pada kemampuan perempuan menciptakan lapangan kerja. Melalui pelatihan keterampilan merajut, perempuan dapat menghasilkan produk-produk rajutan yang bernilai ekonomis. Mitra yang dipilih adalah kelompok masyarakat yaitu anggota Majelis Ta'lim Masjid Al-Ikhlas di Kelurahan Dadok Tunggul Hitam Kecamatan Koto Tangah. Sebagian besar ibu-ibu yang bergabung dalam Majelis Ta'lim yang beranggotakan sebanyak 40 orang adalah ibu rumah tangga yang pada umumnya tidak bekerja dan mempunyai penghasilan yang relatif rendah. Pengabdian Kepada Masyarakat telah dilakukan dengan memberikan pelatihan terhadap ibu-ibu anggota Majelis Ta'lim. Pelatihan yang diberikan adalah membuat kerajinan rajutan tangan. Dalam pelaksanaan kegiatan, para ibu-ibu sangat antusias dalam menyimak penjelasan dan peragaan dari narasumber dan melalui tayangan video. Berbagai model rajutan diajarkan sehingga akan mempermudah mereka dalam membuat berbagai macam rajutan sehingga dapat menumbuhkan semangat berwirausaha dalam meningkatkan pendapatan keluarga.
\end{abstract}

Kata Kunci : Majelis Ta'lim, Pemberdayaan perempuan, Keterampilan

Abstract: Koto tangah district is the most densely populated sub-district. This subdistrict has a large enough female population. empowering women is very important to have an entrepreneurial spirit in developing a productive economy. Empowering women to increase access to knowledge and skills, so as to improve family welfare. Skills training activities are expected to have an impact on women's ability to create employment. through training in knitting skills, women can produce knitted products of economic value. The partner chosen was the community group members of the al-ikhlas mosque assembly council in dadok tunggul hitam village, koto tangah district. most of the mothers who joined the ta'lim assembly with 40 members were housewives who generally did not work and had relatively low incomes. Community service has been carried out by providing training to women members of the ta'lim assembly to develop their economy. The training provided is making hand-knitted crafts. in carrying out the activity, the mothers were very enthusiastic in listening to the explanation and demonstration from the speakers and through the video. Various knitting models are taught so that it will facilitate them in making various kinds of knits so as to foster an entrepreneurial spirit in increasing family income.

Keywords: Majelis ta'lim, women's empowerment, skills 


\section{A. LATAR BELAKANG}

Berdasarkan data BPS Kota Padang tahun 2016, jumlah penduduk Kota Padang menurut jenis kelamin, jumlah perempuan lebih banyak dari pada laki-laki. Dimana perempuan 457.878 orang dan laki-laki 457.063 orang. Sedangkan Kecamatan yang paling padat penduduknya adalah kecamatan Koto Tangah, dimana jumlah penduduk sebanyak 177.881 orang terdiri dari laki-laki 89.769 orang dan perempuan 88.112 orang (BPS, Kota Padang ).

Dengan jumlah perempuan yang cukup besar, perlu pemberdayaan perempuan untuk memiliki jiwa kewirausahaan dalam mengembangkan ekonomi produktif. Pemberdayaan perempuan dapat melalui pengembangan kewirausahaan keluarga. Pemberdayaan perempuan untuk meningkatkan akses terhadap pengetahuan dan keterampilan, sehingga dapat meningkatkan kesejahteraan keluarga. Ada pandangan selama ini kalau perempuan selalu dikonotasikan sebagai manusia pekerja domestik (homemaker) yang dianggap tidak dapat berkontribusi secara aktif di luar rumah sehingga perannya tidak lebih dari sekadar aktivitas dalam rumah. Sekarang justru perempuan memiliki peranan penting dalam mengembangkan ekonomi produktif dan di dunia kerja. (Tuwu, 2018)

Sudah menjadi trend Para Ibu di kota besar maupun di daerah membentuk kelompok majelis taklim. Tujuan majelis taklim ini lebih pada kegiatan sosial yaitu menjalin silaturahmi sekaligus pengajian (Basit, 2010). Sebenarnya pertemuan rutin tersebut bisa menjadi peluang untuk meningkatkan perekonomian keluarga dengan memberikan pelatihan untuk membuat produk sederhana yang mempunyai nilai jual. Di samping sebagai bentuk peningkatan kemampuan para ibu, kegiatan tersebut juga bisa dikembangkan menjadi kegiatan wirausaha para ibu yang bisa menambah perekomian keluarga. (Sutrisno, 2018). Majelis ta'lim perempuan sebagai lembaga pendidikan non formal yang ada di masyarakat memiliki potensi dan peran yang besar manakala dapat diberdayakan secara maksimal. Kegiatan pelatihan kewirausahaan kepada majelis ta"lim diharapkan berdampak pada kemampuan/keberdayaan perempuan menciptakan lapangan kerja. Melalui pelatihan kewirausahaan dalam memanfaatkan potensi alam yang berada di lingkungan setempat, perempuan dapat meningkatkan kesejahteraan hidup mereka.

Kelompok majelis Ta'lim yang dipilih adalah kelompok masyarakat yaitu Majelis Ta'lim Masjid Al-Ikhlas di Kelurahan Dadok Tunggul Hitam Kecamatan Koto Tangah. Dari kunjungan ke tempat Majelis Ta'lim didapatkan informasi sebagian ibu-ibu yang bergabung dalam Majelis Ta'lim adalah ibu rumah tangga dan mempunyai penghasilan yang relatif rendah. Berdasarkan analisis situasi dipilih kelompok majalis taklim ini yang terdiri dari wanita yang pada umumnya tidak bekerja dan mempunyai 
waktu luang. Majelis Ta'lim Mesjid Al-Ikhlas adalah salah satu majelis Taklim yang ada di Kelurahan Tunggul Hitam Padang. Perkumpulan ibuibu yang beranggotakan sebanyak 40 orang. Kegiatan rutin yang biasa dilakukan kelompok ini adalah melakukan Pengajian setiap minggu, arisan bulanan, yasinan serta latihan rebana. Sama halnya dengan majelis taklim lainnya, majelis taklim ini kegiatan lebih berorientasi kepada kegiatan keagamaan dan sosial.

Menurut (Putri \& Darwis, 2015), perempuan dalam kelompok majelis Taklim dapat diberdayakan agar mampu meningkatkan perekonomian keluarga. Perempuan harus mempunyai kemampuan untuk melihat potensi yang ada, peluang-peluang yang mungkin dapat dikembangkan. Menurut (Hasanah, 2013)Pemberdayaan perempuan adalah upaya peningkatan kemampuan perempuan dalam mengembangkan kapasitas dan keterampilannya .

Melihat kondisi ini, melalui program Pengabdian Kepada Masyarakat akan melakukan pelatihan terhadap anggota Majelis Ta'lim untuk bangkit membangun ekonominya. Program pemberdayaan berupa Pelatihan yang diberikan adalah membuat kerajinan rajutan tangan yang tidak mengesampingkan proses pendampingan dalam proses pelatihan (Wildan Saugi \& Sumarno, 2015).

Pelatihan yang diberikan adalah membuat kerajinan rajutan tangan. Pertimbangan dipilihnya pelatihan membuat rajutan tangan karena membuat rajutan tidak sulit, waktu tidak terlalu lama dan bahan baku yang digunakan untuk menghasilkan produk rajutan mudah didapat dan tidak mahal. Bahan baku utama sederhana berupa ram/net, kain, benang, spon dan asksesoris yang mudah dicari dan harganya relatif murah. Kerajinan rajutan dapat berupa rajutan pin, sendal, sepatu bayi, alas meja dan topi, serta sarung tangan untuk pengendara sepeda motor.

\section{B. METODE PELAKSANAAN}

Kegiatan Pengabdian kepada Masyarakat didanai oleh LPPM Universitas Bung Hatta. Untuk melaksanakan kegiatan pengabdian kepada masyarakat, tim terdiri dari dua dosen yang mempunyai bidang keahlian dibidang Pemasaran, satu dosen mempunyai kosentrasi di bidang Manajemen Sumber Daya Manusia serta mahasiswa yang membantu dalam menyiapkan pelatihan merajut. Sebagai tenaga ahli yang mengajarkan keterampilan merajut, tim mengundang seorang tenaga ahli yang memiliki keterampilan merajut dan memiliki usaha rajutan.

Dalam kegiatan pengabdian masyarakat ini, metode pelaksanaan dalam memberikan pelatihan keterampilan membuat kerajinan tangan (handicraft) adalah :

1. Menghubungi Ketua Majelis Ta'lim Al-Ikhlas untuk mendiskusikan pelatihan dan mendata anggotanya yang berprofesi sebagai ibu rumah tangga. 
2. Mengadakan sosialisasi kepada anggota Majelis Ta'lim Al-Ikhlas

3. Memberikan pelatihan, pendidikan dan pendampingan dengan materi

a. Kewirausaahaan dan motivasi.

b. Memberikan keterampilan, berupa pelatihan pembuatan kerajinan rajutan

Kegiatan Pengabdian Kepada Masyarakat Tahap Pertama telah dilaksanakan pada hari Kamis tanggal 5 April 2018 bertempat di Musholla Nurul Wahyi Dadok Tunggul Hitam. Kegiatan yang diberikan adalah pelatihan keterampilan membuat kerajinan tangan/handycraft (kerajinan rajutan).

Dalam pelaksanaan kegiatan, masing-masing anggota Majelis Ta'lim diberi peralatan merajut antara lain jarum dan benang. Selain dipandu oleh tenaga ahli, untuk mempermudah ibu-ibu dalam keterampilan dasar merajut, tim juga menyediakan panduan dalam bentuk gambar serta tayangan video. Selama kegiatan, peserta yang berjumlah 20 orang sangat antusias dalam menyimak penjelasan dan peragaan dari narasumber dan tayangan video. Para peserta anggota Majelis Ta'lim Al-Ikhlas.

Kegiatan PKM ini juga dihadiri oleh Bapak Lurah Dadok Tunggul Hitam, yang mengapresiasi kegiatan pelatihan di kelurahan yang dipimpinannya. Untuk kepentingan publikasi kegiatan sekaligus promosi bagi Universitas Bung Hatta secara umum, Program Studi Manajemen Fakultas Ekonomi secara khusus, kegiatan ini juga diliput oleh media massa. Demi kelancaran pelaksanaan kegiatan PKM, Tim Dosen dibantu oleh mahasiswa Fakultas Ekonomi Universitas Bung Hatta.

Dalam upaya untuk melatih ibu-ibu majelis Taklim ini supaya lebih mahir, kegiatan PKM lanjutan dilaksanakan pada bulan berikutnya. Pelatihan kedua ini ditujukan kepada ibu-ibu Majelis Ta'lim yang memiliki keinginan untuk mendalami keterampilan merajut. PKM lanjutan ini, dihadiri oleh ibu-ibu yang sudah memiliki keterampilan dasar merajut. Dengan keterampilan dasar yang sudah dimiliki, membuat para ibu cepat tanggap dalam memahami hal-hal baru yang diajarkan oleh tenaga ahli. Pada tahap ini diberikan pelatihan berbagai model rajutan yang akhirnya akan mempermudah mereka dalam membuat berbagai macam rajutan sehingga dapat menumbuhkan semangat berwirausaha dalam meningkatkan pendapatan keluarga.

\section{HASIL DAN PEMBAHASAN}

Berikut adalah gambar seluruh peserta pelatihan dengan Tim Pengabdian Masyarakat yang terdiri ibu-ibu majelis Ta'lim ( gambar 1). Pada gambar 2 terlihat ibu-ibu peserta pelatihan rajutan antusias dalam belajar. Peserta dibagi atas dua kelompok yaitu kelompok pemula yang belum pernah belajar merajut dan kelompok yang sudah pernah merajut 
secara sederhana. Proses kegiatan pengabdian dapat dilihat pada Gambar 1 dan Gambar 2 berikut.

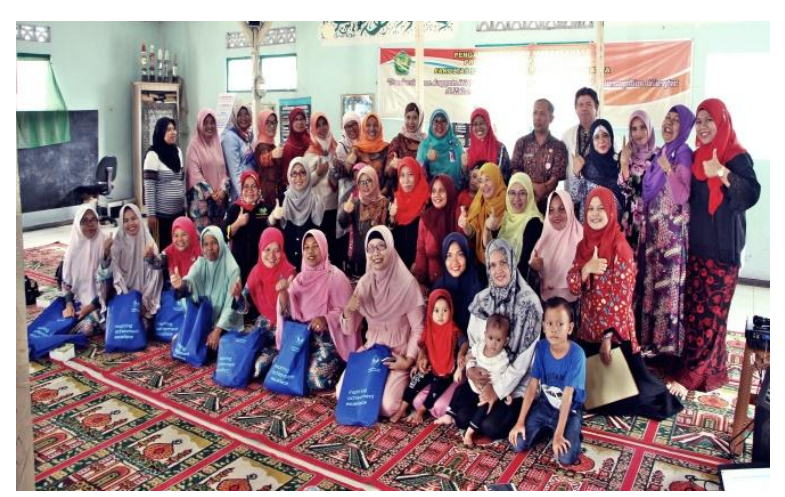

Gambar 1. Peserta Pelatihan

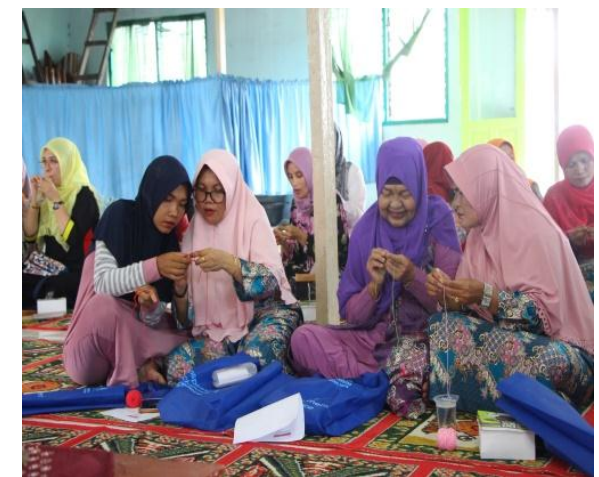

Gambar 2. Peserta Merajut

Berikut adalah produk hasil pelatihan merajut
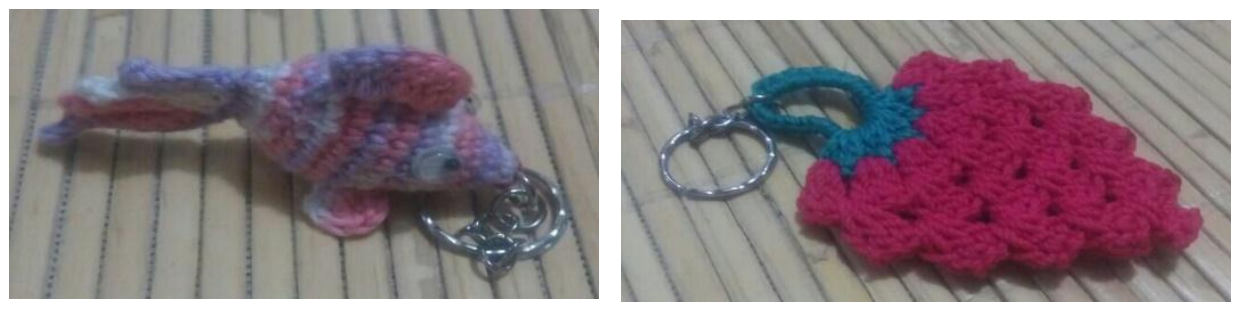

Gambar 3. Contoh Gantungan Kunci dari Rajutan
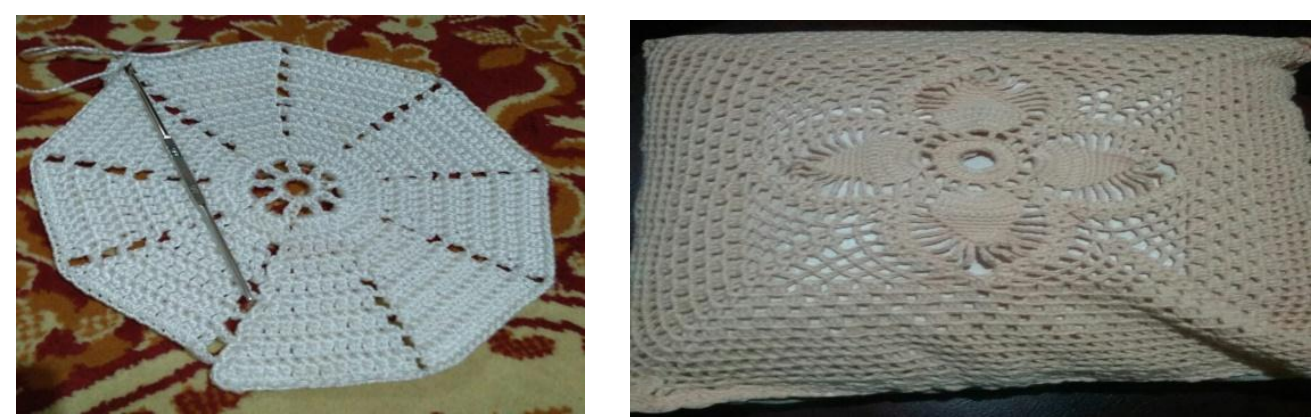

Gambar 4. Taplak Meja dan Sarung Bantal

\section{SIMPULAN DAN SARAN}

Program pengabdian masyarakat dalam rangka memberdayakan kelompok majelis taklim Masjid Al-Ikhlas di Kelurahan Dadok Tunggul Hitam ini berupa pembuatan berbagai kerajinan dari rajutan. Program pelatihan ini berjalan dengan baik, karena kerajinan rajutan yang dihasilkan mudah untuk dibuat. Tidak perlu memakan waktu yang lama untuk bisa menguasai keterampilan merajut. Hasil rajutan ini selain bisa digunakan sendiri, juga bisa dijual sebagai souvenir. Dengan memiliki keterampilan merajut, ibu-ibu majelis taklim bisa membuat berbagai kerajinan rajutan yang dapat dijual untuk meningkatkan perekonomian keluarga. Saran yang dapat diusulkan dengan adanya program pemberdayaan perempuan melalui pelatihan keterampilan merajut ini 
adalah untuk mendapatkan produk rajutan yang baik dan bisa dijual, pelatihan ini tidak hanya dilakukan sekali. Harus ada beberapa kali sesi latihan baik untuk merajut bagi pemula maupun yang sudah memiliki keterampilan dasar merajut.

\section{DAFTAR RUJUKAN}

Basit, A. (2010). Pemberdayaan Majelis Ta'lim Perempuan Dalam Perspektif Manajemen Dakwah. Jurnal Dakwah Dan Komunikasi, 4(2).

Hasanah, S. (2013). Pemberdayaan Perempuan Melalui Kegiatan Ekonomi Berkeadilan (Simpan Pinjam Syariah Perempuan). $S A W W A, 9(1), 71-88$.

Hurriyati, R. (2010). Bauran Pemasaran dan Loyalitas Konsumen. Bandung: Alphabeta.

Kotler, Philip \& Keller, K. L. (2009). Manajemen Pemasaran (13th ed.). Jakarta: Erlangga.

Kotler, Philip dan Amstrong, G. (2008). Prinsip-prinsip Pemasaran (12th ed.). Jakarta: Erlangga.

Putri, O. N., \& Darwis, R. S. (2015). Pemberdayaan Perempuan Kepala Keluarga. Prosiding Penelitian Dan Pengabdian Kepada Masyarakat, 2(2), 29-283. https://doi.org/10.24198/jppm.v2i2.13538

Sutrisno, S. (2018). Pemberdayaan Anggota Majelis Taklim Melalui Usaha Susu Kedelai Dan Nugget. Journal of Community Service, 2(2), 21-28. https://doi.org/10.26533/comvice.v2i2.167

Tuwu, D. (2018). Peran Pekerja Perempuan Dalam Memenuhi Ekonomi Keluarga: Dari Peran Domestik Menuju Sektor Publik. Al-Izzah: Jurnal Hasil-Hasil Penelitian, 13(1), 63. https://doi.org/10.31332/ai.v13i1.872

Wildan Saugi, \& Sumarno. (2015). Pemberdayaan Perempuan Melalui Pelatihan Pengolahan Bahan Pangan Lokal. Jurnal Pendidikan Dan Pemberdayaan Masyarakat, 2(November), 226-238. 